\title{
The effects of cell-free extracts derived from probiotic strains Bifidobacterium bifidum and Lactobacillus reuteri on the proliferation and biofilm formation by Lactobacillus reuteri in vitro
}

\section{V. Knysh*}

State Institution “I. Mechnikov Institute of Microbiology and Immunology of National Academy of Medical Sciences of Ukraine”, Kharkiv

Key words: proliferation, probiotic derivatives, Bifidobacterium bifidum, Lactobacillus reuteri.

\section{Zaporozhye} medical journal 2019; 21 (6), 828-834 Dol: $10.14739 / 2310-1210$ 2019.6.186711

*E-mail:

knysh_oksana@ukr.net
The aim of the research was to investigate the ability of cell-free extracts, containing derivatives of probiotic strains Bifidobacterium bifidum and Lactobacillus reuteri, to influence the proliferation and biofilm formation by Lactobacillus reuteri in vitro; to evaluate the prospects for the creation of new metabiotics and means of increasing the overall productivity of probiotic cell biomass based on them.

Materials and methods. Cell-free extracts were obtained from probiotic strains B. bifidum 1 and L. reuteri DSM 17938 by the authors method. Probiotic strain L. reuteri DSM 17938 used as a test culture. The investigation of the proliferation and biofilm formation by $L$. reuteri was carried out by spectrophotometric method using a microtiter-plate reader "Lisa Scan EM" (Erba Lachema s.r.o., Czech Republic).

Results. It has been established that the cell-free extract obtained from $L$. reuteri culture grown in its own disintegrate, supplemented with glycerol and glucose, is the only one of all studied, which stimulates both proliferation and biofilm formation by $L$. reuteri. The cell-free extracts, obtained from $L$. reuteri and $B$. bifidum disintegrates and from $L$. reuteri culture, grown in its own disintegrate, stimulate proliferation of test-culture to varying degrees (depending on the type of extract and its content in the culture medium), but have a significant inhibitory effect on the biofilm formation by $L$. reuteri. The extract, obtained from $B$. bifidum culture, grown in its own disintegrate, does not have a significant effect on proliferation and greatly suppresses the biofilm formation by L. reuteri.

Conclusions. The results of the study allow us to positively evaluate the prospects for the creation of new metabiotics based on probiotic derivatives. Cell-free extract, obtained from $L$. reuteri culture, grown in its own disintegrate supplemented with glycerol and glucose can contribute to the survival and facilitate inoculation of the introduced probiotic in the gastrointestinal tract when used together.

Derivative-containing extracts with a pronounced growth-stimulating effect can be the basis for creating the means of increasing the overall productivity of the probiotic cell biomass. The use of such means will increase the economic efficiency of probiotic cultures production. Obtained data induce further study of the biochemical composition, elucidation of the mechanism of cellfree extracts action and confirmation of their efficacy in vivo.

Ключові слова: проліферація,

Аеривати

пробіотиків,

Bifidobacterium

bifidum,

Lactobacillus

reuteri.

Запорізький

медичний

журнал. - 2019. -

T. 21, № 6(117).

C. 828-834
Вплив безклітинних екстрактів, що отримані з пробіотичних штамів Bifidobacterium bifidum та Lactobacillus reuteri, на проліферацію та біоплівкоутворення Lactobacillus reuteri in vitro

\section{О. В. Книш}

Мета роботи - дослідити здатність безклітинних екстрактів, що містять деривати пробіотичних штамів Bifidobacterium bifidum і Lactobacillus reuteri, впливати на проліферацію та біоплівкоутворення Lactobacillus reuteri in vitro; оцінити перспективи створення на їхній основі нових метабіотиків, засобів підвищення загальної продуктивності клітинної біомаси пробіотика.

Матеріали та методи. Безклітинні екстракти отримували з пробіотичних штамів B. bifidum 1 i L. reuteri DSM 17938 за методом, що розроблений авторами. Пробіотичний штам L. reuteri DSM 17938 використовували як тест-культуру. Проліферацію та біоплівкоутворення L. reuteri досліджували спектрофотометричним методом за допомогою мікропланшетного аналізатора «Lisa Scan EM» («Erba Lachema s.r.o.», Чеська Республіка).

Результати. Безклітинний екстракт, який отримали з культури L. reuteri, що вирощена у власному дезінтеграті з додаванням гліцерину та глюкози, є єдиним з усіх досліджених, котрий стимулює і проліферацію, і біоплівкоутворення L. reuteri. Безклітинні екстракти, що отримані з дезінтегратів $L$. reuteri і $B$. bifidum і з культури $L$. reuteri, вирощеної у власному дезінтеграті, стимулюють проліферацію тест-культури різною мірою (залежно від типу екстракту та його вмісту в середовищі культивування), але мають значущий інгібіторний вплив на біоплівкоутворення L. reuteri. Екстракт, що отриманий з культури B. bifidum, вирощеної у власному дезінтеграті, не має істотного впливу на проліферацію та суттєво пригнічує біоплівкоутворення L. reuteri.

Висновки. Результати дослідження дають можливість позитивно оцінити перспективи створення нових метабіотиків на основі пробіотичних похідних. Безклітинний екстракт, що отриманий з культури L. reuteri, яка вирощена у власному дезінтеграті з додаванням гліцерину та глюкози, може сприяти виживанню та полегшувати інокуляцію введеного пробіотика у шлунково-кишковому тракті при поєднаному використанні.

Дериват-вмісні екстракти з вираженим ріст-стимулювальним ефектом можуть стати основою для створення засобів підвищення загальної продуктивності клітинної біомаси пробіотика. Використання таких засобів підвищить економічну ефективність виробництва пробіотичних культур. Результати спонукають до продовження вивчення біохімічного складу, з'ясування механізму дії безклітинних екстрактів і підтвердження їхньої ефективності in vivo. 


\section{Влияние бесклеточных экстрактов, полученных из пробиотических штаммов Bifidobacterium bifidum и Lactobacillus reuteri, на пролиферацию и биопленкообразование Lactobacillus reuteri in vitro}

\section{0. В. Кныш}

Цель работы - исследовать способность бесклеточных экстрактов, содержащих дериваты пробиотических штаммов Bifidobacterium bifidum и Lactobacillus reuteri, влиять на пролифрерацию и биопленкообразование Lactobacillus reuteri in vitro; оценить перспективы создания на их основе новых метабиотиков и средств повышения общей производительности клеточной биомассы пробиотика.

Материалы и методы. Бесклеточные экстракты получали из пробиотических штаммов B. bifidum 1 и L. reuteri DSM 17938 методом, разработанным авторами. Пробиотический штамм L. reuteri DSM 17938 использовали в качестве тест-культуры. Пролиферацию и биопленкообразование L. reuteri исследовали спектрофотометрическим методом с помощью микропланшетного анализатора «Lisa Scan EM» («Erba Lachema s.r.o.», Чешская Республика).

Результаты. Бесклеточный экстракт, полученный из культуры L. reuteri, выращенной в собственном дезинтеграте с добавлением глицерина и глюкозы, - единственный из всех исследованных, который стимулирует и пролиферацию, и биопленкообразование L. reuteri. Бесклеточные экстракты, полученные из дезинтегратов L. reuteri и B. bifidum и культуры L. reuteri, выращенной в собственном дезинтеграте, стимулируют пролиферацию тест-культуры в разной степени (в зависимости от типа экстракта и его содержания в среде культивирования), но имеют значительное ингибиторное влияние на биопленкообразование L. reuteri. Экстракт, полученный из культуры B. bifidum, выращенной в собственном дезинтеграте, не имеет существенного влияния на пролиферацию и значительно подавляет биопленкообразование L. reuteri.

Выводы. Результаты исследования позволяют положительно оценить перспективы создания новых метабиотиков на основе пробиотических производных. Бесклеточный экстракт, полученный из культуры L. reuteri, выращенной в собственном дезинтеграте с добавлением глицерина и глюкозы, может способствовать выживанию и облегчать инокуляцию введенного пробиотика в желудочно-кишечном тракте при совместном использовании.

Дериват-содержащие экстракты с выраженным рост-стимулирующим эфффектом могут стать основой для создания средств повышения общей продуктивности клеточной биомассы пробиотика. Использование таких средств повысит экономическую эффрективность производства пробиотических культур. Полученные данные побуждают к дальнейшему изучению биохимического состава, выяснения механизма действия бесклеточных экстрактов и подтверждения их эфффективности in vivo.

Lactobacillus reuteri is one of the first microorganisms colonizing the gut of newborns and determining the subsequent development of the immune system. This microorganism is an important natural inhabitant of human breast milk, skin, urinary tract, and occupies a special position in the gut ecosystem [1-3]. L. reuteri belongs to probiotic microorganisms due to a number of beneficial effects for the host organism. These lactobacilli regulate the composition of the microbiotas. They inhibit the growth of opportunistic and pathogenic microorganisms due to the production of antimicrobial substances (organic acids, ethanol, reuterin and reutericyclin) and compete for receptors and binding sites on the intestinal mucosa with other microbes, providing colonization resistance. Thereby $L$. reuteri strengthens the intestinal barrier and reduces the microbial translocation across the intestinal epithelium. It has been shown that L. reuteri have anti-inflammatory activity: it decreases the production of many pro-inflammatory cytokines, promote the formation of $T_{\text {reg }}$ cells and stimulate ptoduction of IL-10 [1]. L. reuteri also exhibits anti-cancer activity due to production of anti-carcinogenic compounds (short chain fatty acids) and reduction of intestinal absorption of endogenous and exogenous carcinogens [2,3].

According to the research of Gerhard Reiter and Tomonari Mitsuoka, in the middle of the past century L. reuteri was one of the dominant lactobacilli. In recent decades, along with a decrease in the bacterial diversity of the gut microbiota, reduction of the $L$. reuteri population size and low its prevalence in human is observed [4]. This phenomenon has arguably contributed to an increase in human immune dysregulation and other negative health consequences. In this regard, scientists proposed the Microbiome Rewil- ding Hypothesis [5]. This hypothesis prompts to realize the need for "reintroduction" and engraftment of $L$. reuteri in the human gut.

L. reuteri as probiotic species is produced by BioGaia AB. L. reuteri DSM 17938 is the daughter strain of $L$. reuteri ATCC 55730 which has an important advantage: it does not possess undesirable plasmid resistance to antibiotics. There is much evidence of the effectiveness of $L$. reuteri DSM 17938 for the treatment and prevention of diseases in infants, children and adults: infantile colic and regurgitation, necrotizing enterocolitis, functional constipation or functional abdominal pain, diarrhea $[1,3,4,6]$. However, most studies show that the beneficial effect of $L$. reuteri is temporary and disappears after discontinuation of the probiotic taking [7-9]. Orally taken bacteria do not survive due to the damaging effects of physicochemical factors in the gastrointestinal tract, the effects of the host's immune system, competition with commensal and pathogenic bacteria [8]. Probably one of the serious reasons why $L$. reuteri leaves the gastrointestinal tract is the lack of important dietary substrates.

Taking into account the importance of $L$. reuteri for human health and significant benefits for functioning of the hosts' immune system, the development of methods aimed at improving survival and facilitating the inoculation of lactobacilli in the gastrointestinal tract has a significant therapeutic value. One way to increase the survival of bacteria is to protect them by encapsulation or adhesion to a semi-permeable biocompatible dextranomer microsphere in the form of a biofilm [8]. The second way is to use growth promoting prebiotic ingredients: $\beta$-galacto- oligosaccharides, lactulose, fructo-oligosaccharides, inulin, isomaltose [10]. An alternative approach to increasing colonization of
Кнючевые слова: пролиферация, Аериваты пробиотиков, Bifidobacterium bifidum, Lactobacillus reuteri. журнал. - 2019. T. 21, № 6(117). C. 828-834 
the gastrointestinal tract by beneficial microorganisms and enhancing the protective properties of the immune system is using the biological activity of the probiotics' derivatives [11-13].

\section{The aim}

The aim of the research was to investigate the ability of cell-free extracts, containing derivatives of probiotic strains Bifidobacterium bifidum and Lactobacillus reuteri, to influence the proliferation and biofilm formation by Lactobacillus reuteri in vitro; to evaluate the prospects for the creation of new metabiotics and means of increasing the overall productivity of probiotic cell biomass based on them.

\section{Materials and methods}

Five cell-free extracts containing probiotics' derivatives were investigated:

$-L$ - filtrate of $L$. reuteri disintegrate;

- $M L$ - filtrate of $L$. reuteri culture, grown in $L$. reuteri disintegrate;

- MLG - filtrate of $L$. reuteri culture, grown in $L$. reuteri disintegrate supplemented with $0.8 \mathrm{M}(73.7 \mathrm{~g} / \mathrm{l})$ glycerol and $0.4 \mathrm{M}(72.1 \mathrm{~g} / \mathrm{l})$ glucose;

$-B$ - filtrate of $B$. bifidum disintegrate;

$-M B-$ filtrate of $B$. bifidum culture, grown in $B$. bifidum disintegrate.

Disintegrates and probiotics' cultures were obtained from probiotic strains $B$. bifidum 1 (from medical product "Bifidumbacterin-Biopharma", JSC Biopharma, Ukraine) and L. reuteri DSM 17938 (from medical product "BioGaia", BioGaia Production AB, Sweden) using the method developed by the authors [14]. Disintegrates were prepared by tenfold cyclic freezing-thawing of the bacterial suspensions with an optical density of 10 units on the McFarland scale. Cultures were obtained by growing probiotic microorganisms in their own disintegrates for 72 hours. Disintegrates and cultures were centrifuged and passed through membrane filters (Vladipor, RF) with a pore diameter of $0.2 \mu \mathrm{m}$ to remove microbial cells and cellular debris. As a result, cell-free extracts were received.

The probiotic strain L. reuteri DSM 17938 was used as a proliferating and biofilm-forming test culture. The lyophilized microbial mass was rehydrated and recovered by cultivation in tryptone soya broth (TSB; HiMedia, India) in microaerophilic conditions for 24 hours at $37^{\circ} \mathrm{C}$. After checking the purity of the culture, the cells were washed three times to remove the components of the nutrient medium. For this, the cell suspension was centrifuged for $10 \mathrm{~min}$ at $1500 \mathrm{~g}$ and the pellet was resuspended in a sterile isotonic saline solution $(0.9 \% \mathrm{NaCl})$. The inoculum was prepared from the suspension of washed cells. It was a microbial suspension in a physiological saline solution with an optical density of 10 units on the McFarland scale $\left(\sim 10^{9} \mathrm{CFU} / \mathrm{ml}\right)$. The turbidity of the suspension was measured using the Densi-La-Meter II device (PLIVA-Lachema Diagnostika, Czech Republic).

The study of the effect of cell-free extracts on the L. reuteri proliferation was performed in sterile 96-well polystyrene microtiter plates (JSC "Eximcargotrade", Ukraine). TSB supplemented with $1 \%$ glucose, cell-free extracts and inoculums were added into the test wells in the ratio of $8: 1: 1 ; 6: 3: 1$ and $4: 5: 1$. Thus, the final concentration of each extract in the cultivation medium was $10 \%$ vol, $30 \%$ vol or $50 \%$ vol. TSB supplemented with $1 \%$ glucose, physiological saline (PhS) and inoculums were added into the positive control wells $(P C)$ in the same ratio: $P C_{10}(10 \%$ vol of the PhS in the cultivation medium); $P C_{30}(30 \%$ vol of the $\mathrm{PhS}$ in the cultivation medium); $P C_{50}(50 \% \mathrm{vol}$ of the $\mathrm{PhS}$ in the cultivation medium). The final concentration of microbial cells in the test and positive control wells was $\sim 10^{8} \mathrm{CFU} / \mathrm{ml}$. The negative control wells (NC) contained only TSB. The plates were covered with lids and incubated in microaerophilic static conditions for 24 hours at 35-37 ${ }^{\circ} \mathrm{C}$. The optical density (OD) of the wells was measured at $578 \mathrm{~nm}$ using a microtiter-plate reader "Lisa Scan EM" ("Erba Lachema s.r.o.", Czech Republic). The inhibition (or stimulation) indices were calculated by the formula: Inhl $(\mathrm{Stl})=\left(\Delta \mathrm{OD}-\Delta \mathrm{OD}_{\mathrm{PC}}\right) \div \Delta \mathrm{OD}_{\mathrm{PC}} \times 100 \%$, where $\Delta \mathrm{OD}$ and $\Delta \mathrm{OD}_{\mathrm{PC}}$ are the optical density gain in the test and positive control wells within 24 hours, respectively.

The study of the effect of cell-free extracts on the biofilm formation by $L$. reuteri. Cultivation of biofilms in the wells and subsequent detection by stain for biofilm recognition were performed according to the method of Stepanovic' et al. [15]. After measuring the optical density of the wells the plates were continued to incubate in microaerophilic static conditions for 24 hours at $35-37^{\circ} \mathrm{C}$. Than the contents of the wells were decanted into discard container. Each well was carefully washed three times with sterile $0.1 \mathrm{M}$ phosphate-buffered saline (PBS; pH 7.2) using an appropriate micropipette. Plates were drained in an inverted position. Attached biofilms were fixed by exposing them to hot air at $60^{\circ} \mathrm{C}$ for $60 \mathrm{~min}$. Then they were stained by $1 \%$ crystal violet for $15 \mathrm{~min}$. After that, wells were washed ten times with purified water using a micropipette. Ethanol as an eluent was gently added into the wells for resolubilization of the dye. Microtiter plate covered with the lid and was left at room temperature for $30 \mathrm{~min}$. The optical density (OD) of the eluate in the test and control wells was measured at $630 \mathrm{~nm}$ by using a microtiter-plate reader "Lisa Scan EM" ("Erba Lachema s.r.o.", Czech Republic). Based on the OD values obtained for $\mathrm{NC}$ and test samples, biofilm formation was defined as:

- weak $\left(O D_{\mathrm{NC}}<\mathrm{OD} \leq 2 \times O D_{\mathrm{NC}}\right)$;

- moderate $\left(2 \mathrm{xOD}_{\mathrm{NC}}<\mathrm{OD} \leq 4 \times \mathrm{xOD}_{\mathrm{NC}}\right)$;

- strong $\left(4 \mathrm{xOD}_{\mathrm{NC}}<\mathrm{OD}\right)$;

- no biofilm formation $\left(\mathrm{OD} \leq \mathrm{OD}_{\mathrm{NC}}\right)$, according to the method for quantification of biofilm formation proposed by In Lee S. et al. [16].

The inhibition (or stimulation) indices were calculated by the formula: Inhl $(\mathrm{Stl})=\left(\mathrm{OD}-O D_{\mathrm{PC}}\right) \div O D_{P C} \times 100 \%$, where $\mathrm{OD}$ and $\mathrm{OD}_{\mathrm{PC}}$ are optical density of the test and control samples, respectively.

All experiments were performed three times. Each sample was tested in triplicate. Obtained data were statistically processed with Excel 2010 software (Microsoft, USA). Average values of obtained indices (OD or $\triangle O D$ ) with standard deviations (SD) were determined. The significance of the difference between the obtained indices of the test and control groups was determined by Student's t-test. Differences were considered significant at $P<0.05$. 


\section{Results}

At the first stage of research, the effect of cell-free extracts on $L$. reuteri proliferation was studied. The data presented in Fig. 1 suggests that an increase in the volume of the PhS replacing the nutrient medium in the control sample from $10 \%$ to $30 \%$ and from $10 \%$ to $50 \%$, is accompanied by a decrease in the optical density gain of the culture by an average of $13.8 \%$ and $26.0 \%$, respectively. This is a dilution effect due to a decrease in the amount of nutrients in the cultivation medium. Introduction into the cultivation medium of the $L$ extract at a concentration of $10 \%$ leads to a significant increase in the optical density gain of the culture compared to $P C_{10}$ (Stl is $24.5 \%$ ). ML and MLG cell-free extracts at a concentration of $10 \%$ do not have a significant effect on the optical density gain of the culture.

The increase of $L, M L$ and $M L G$ extracts' content in the cultivation medium for up to $30 \%$ is accompanied by a significant increase in the optical density gain of the culture in comparison with $P C_{30}$ (Stls are $101.4 \% ; 54.3 \%$ and $30.0 \%$, respectively). Introduction into the cultivation medium of $L$ and $M L$ extracts at a concentration of $50 \%$ results in a significantly increase of the optical density gain of the culture compared to $P C_{50}$ (Stls are $81.7 \%$ and $32.7 \%$, respectively). MLG extract at $50 \%$ content in the cultivation medium does not have a significant effect on optical density gain of culture compared to $P C_{50}$.

As shown in Fig. 2, cell-free extract $B$ in the composition of the cultivation medium at a concentration of $10 \%$ does not have a significant effect on the optical density gain of the culture compared to $P C_{10}$. An increase in the content of this extract in the composition of the cultivation medium to $30 \%$ and $50 \%$ leads to a significant increase of the culture optical density gain compared to the $P C_{30}$ and $P C_{50}$ (Stls are $19.5 \%$ and $16.3 \%$, respectively). The presence of $B$ extract in the cultivation medium does not affect the culture optical density gain.

At the second stage of research, the effect of cell-free extracts on biofilm formation by $L$. reuteri was studied. Optical density of the eluate enables to indirectly judge the biofilm formation by bacteria. An increase in the volume of the PhS replacing the nutrient medium in the control sample from $10 \%$ to $30 \%$ and from $10 \%$ to $50 \%$, is accompanied by a decrease in the optical density of the eluate by an average of $8.9 \%$ and $29.8 \%$, respectively (Fig. 3). The biofilm formation by L. reuteri culture at $10 \%, 30 \%$ and $50 \%$ content of the PhS in the cultivation medium is defined as strong. The introduction into the cultivation medium of extract $L$ at a concentration of $10 \%$ is accompanied by a decrease in the optical density of the eluate compared with $P C_{10}$ (Inhl is $16.3 \%$ ). Extract $M L$ at a concentration of $10 \%$ does not affect the optical density of the eluate. An increase in the concentration of extracts of $L$ and $M L$ to $30 \%$ in the cultivation medium is accompanied by a significant decrease of the biofilm formation by test-culture compared to $P C_{30}$ (Inhls are $63.6 \%$ and $51.3 \%$, respectively).

But, despite this, the biofilm formation of the test culture is defined as strong. An increase in the content of $L$ and $M L$ extracts in cultivation medium up to $50 \%$ leads to pronounced inhibition of biofilm formation by $L$. reuteri compared to $P C_{30}$ (Inhls are $78.0 \%$ and $48.3 \%$, respectively). It should be noted that in the presence of $L$ extract, biofilm

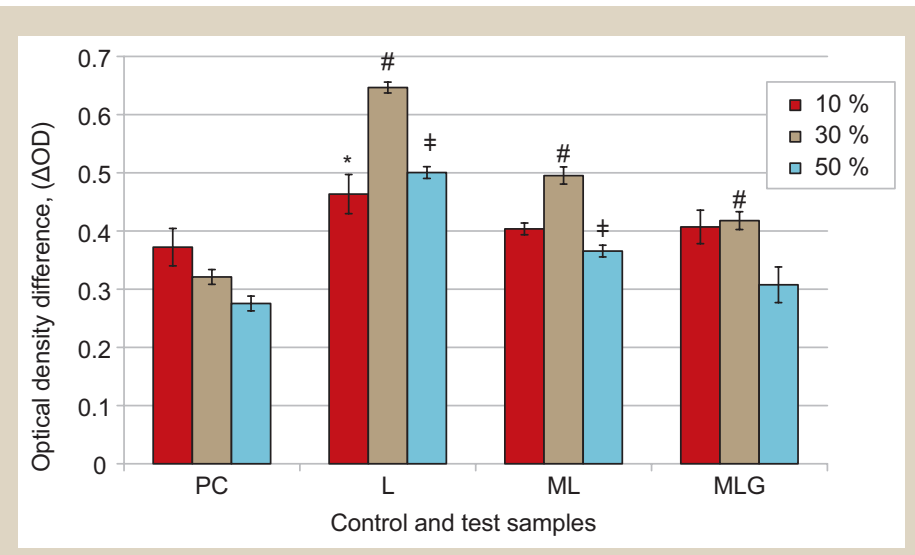

Fig. 1. The effect of cell-free extracts derived from $L$. reuteri on the proliferation of $L$. reuteri (average $\triangle \mathrm{OD} \pm \mathrm{SD}$, at $578 \mathrm{~nm}, \mathrm{n}=3$ ).

PC: positive controls $\left(P C_{10} ; P C_{30} ; P C_{50}\right)$; $L$; filtrate of $L$. reuteri disintegrate; $M L$ filtrate of $L$. reuteri culture, grown in $L$. reuteri disintegrate; MLG: filtrate of $L$. reuteri culture, grown in $L$. reuteri disintegrate supplemented with glycerol and glucose; *: the differences are significant compared to the $P C_{10}$; \#: compared to the $P C_{30}$; $\neq$ : compared to the $P C_{50}, P<0.05$.

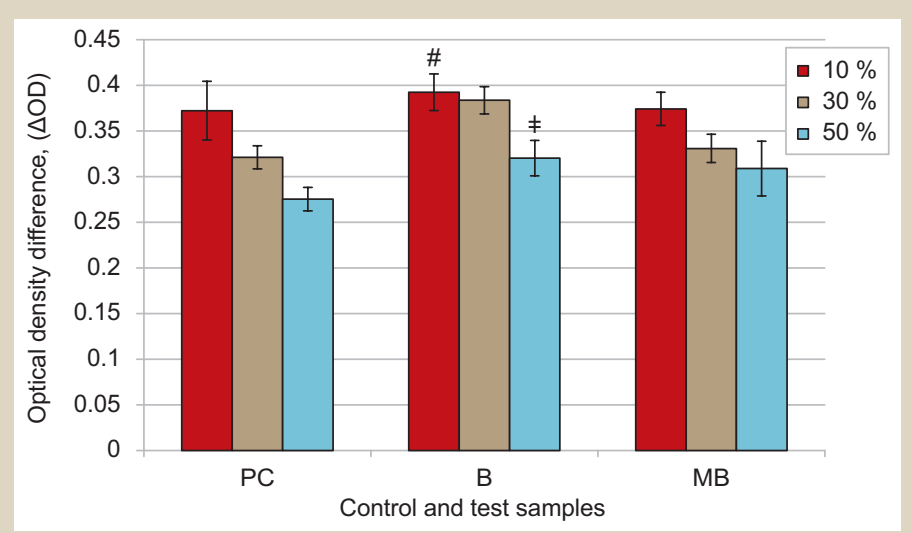

Fig. 2. The effect of cell-free extracts derived from $B$. bifidum on the proliferation of $L$. reuteri (average $\triangle O D \pm S D$, at $578 \mathrm{~nm}, \mathrm{n}=3$ ).

PC: positive controls $\left(P C_{10} ; P C_{30} ; P C_{50}\right) ; B$ : filtrate of $B$. bifidum disintegrate; MB: filtrate of $B$. bifidum culture, grown in $B$. bifidum disintegrate; \#: the differences are significant compared to the $P C_{30}$; ¥: compared to the $P C_{50}, P<0.05$.

formation by $L$. reuteri culture becomes moderate. MLG extract at $10 \%$ and $30 \%$ concentration in the cultivation medium significantly stimulates the biofilm formation of the test culture (Stls are $32.9 \%$ and $25.5 \%$, respectively). The degree of biofilm formation by $L$. reuteri in a cultivation medium containing $50 \%$ MLG extract does not differ from biofilm formation by test culture in the $P C_{50}$.

As can be seen from the data presented in Fig. 4, B and $M B$ extracts significantly inhibit biofilm formation of $L$. reuteri in a dose dependent manner. Calculated Inhls of biofilm formation under the influence of introducing $B$ extract into the cultivation medium at concentrations of $10 \% ; 30 \%$ and $50 \%$ are: $50.0 \% ; 82.9 \%$ and $83.7 \%$, respectively. The Inhls after the introduction of $M B$ extract into the cultivation medium at the same concentrations are: $31.0 \% ; 73.8 \%$ and $73.1 \%$, respectively. Biofilm formation by $L$. reuteri culture in the presence of extracts $B$ and $M B$ in the cultivation medium at concentrations of $30 \%$ and $50 \%$ is defined as moderate. 


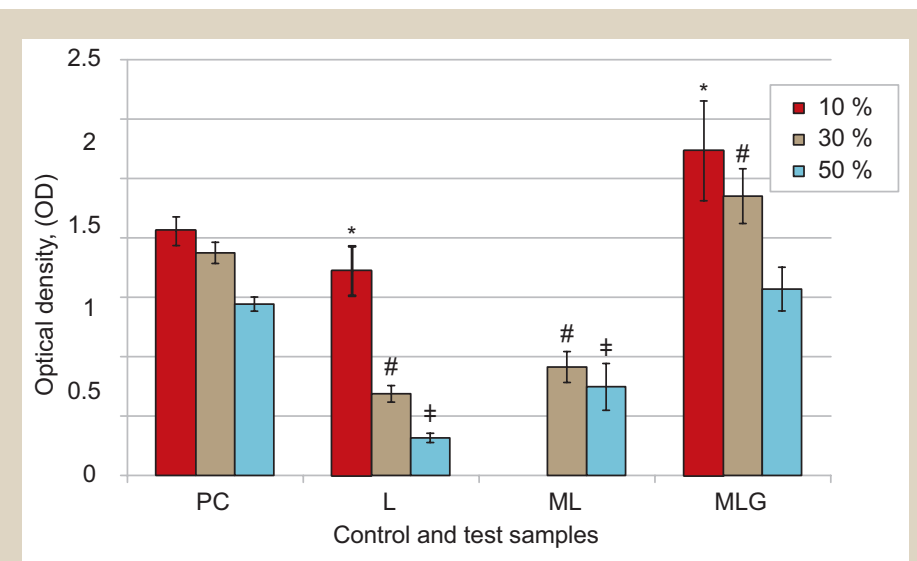

Fig. 3. The effect of cell-free extracts derived from $L$. reuteri on the biofilm formation by $L$. reuteri (average $\mathrm{OD} \pm \mathrm{SD}$, at $630 \mathrm{~nm}, \mathrm{n}=3$ ).

PC: positive controls $\left(P C_{10} ; P C_{30} ; P C_{55}\right)$; $L$ : filtrate of $L$. reuteri disintegrate; ML: filtrate of $L$. reuteri culture, grown in $L$. reuteri disintegrate; MLG: filtrate of $L$. reuteri culture, grown in $L$. reuteri disintegrate supplemented with glycerol and glucose; *: the differences are significant compared to the $P C_{10} ;$; : compared to the $P C_{30}$; $\neq$ : compared to the $P C_{50}, P<0.05$.

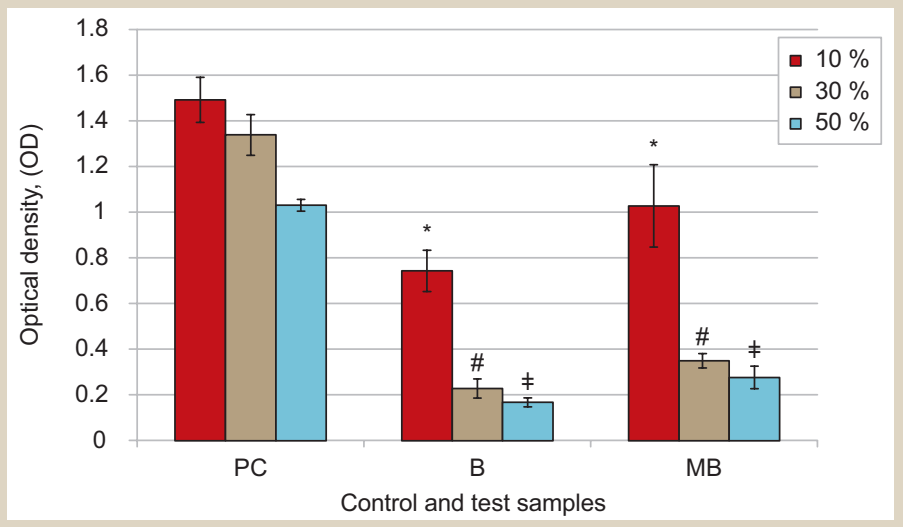

Fig. 4. The effect of cell-free extracts derived from B. bifidum on the biofilm formation by $L$. reuteri (average $\mathrm{OD} \pm \mathrm{SD}$, at $630 \mathrm{~nm}, \mathrm{n}=3$ ).

$\mathrm{PC}$ : positive controls $\left(P \mathrm{C}_{10} ; P \mathrm{C}_{30} ; P \mathrm{C}_{5}\right)$; $\mathrm{B}$ : filtrate of $B$. bifidum disintegrate; MB: filtrate of $B$. bifidum culture, grown in $B$. bifidum disintegrate; *: the differences are significant compared to the $P C_{10}$; \#: compared to the $P C_{30}$; : compared to the $P C_{50}, P<0.05$.

\section{Discussion}

Summarizing the data obtained at the first stage of research, it should be noted that cell-free extracts obtained from $L$. reuteri disintegrate and culture, grown in its own disintegrate, stimulate the proliferative activity of $L$. reuteri to a much greater degree than the extract obtained from $B$. bifidum disintegrate. According to the degree of stimulatory effect on the $L$. reuteri proliferation, cell-free extracts arranged in ascending order: $B<M L G<M L<L$. The stimulation abilities of cell-free extracts enhance with increasing concentration in the cultivation medium from $10 \%$ to $30 \%$ and weaken with increasing concentration to $50 \%$ due to the dilution effect. The most pronounced stimulatory effect on $L$. reuteri proliferation is exerted by extract $L$, containing disintegration products of $L$. reuteri. The less pronounced effect of $M L$ and $M L G$ extracts on the proliferative activity of $L$. reuteri is obviously associated with the inhibition effect of some metabolites contained in these extracts. One of these metabolites can be reuterin, produced by $L$. reuteri when cultivated in a glycerin-containing medium. It is known that reuterin exhibits pronounced antimicrobial activity toward to representatives of many genera of bacteria, fungi and protozoa in concentrations $4-5$ times lower than those that can inhibit the growth of lactic acid bacteria. It is noteworthy that among all species of the genus Lactobacillus L. reuteri produces the highest concentrations of reuterin and is most resistant to its antimicrobial activity [1]. In addition to reuterin, proliferative activity can be suppressed by lactic acid produced by lactobacilli in the process of cultivation. Lactic acid due its chelating properties can capture essential for growth elements, such as iron $[17,18]$.

Data obtained at the second stage of research, allow us to conclude that all cell-free extracts, with the exception of $M L G$, inhibit biofilm formation by $L$. reuteri. According to the degree of inhibitory effect on the $L$. reuteri proliferation, cell-free extracts arranged in ascending order: $M L<L<M B<B$. The inhibitory and stimulatory abilities of cell-free extracts are in a concentration-dependent way. The chemical stimuli that influence the development of biofilms include nutrients and metabolites, quorum sensing molecules, and antimicrobials. According to recent studies, bacterial exposure to subinhibitory antimicrobials of many chemically different classes increases biofilm formation. This phenomenon can be considered as a quick and nonspecific way to protect the population from chemical threats. It can be explained by relying on the fundamental biomedical paradigm of hormesis, according to which small doses stimulate, and large inhibit biological parameters [19]. We assume that stimulatory effect of MLG extract on biofilm formation by $L$. reuteri is related to the content in the extract of reuterin, which has antimicrobial activity. To date, we have not established which mechanisms underlie the inhibitory effect of other extracts on the biofilm formation by $L$. reuteri. This issue is to be studied further. However, we assume the existence of at least two mechanisms of inhibition. The first mechanism is based on the ability of disintegration products, which are signal molecules, to suppress the expression of genes responsible for biofilm formation. The second mechanism is associated with the involvement of some structural components of bacteria (EPSs, proteins, for example) in non-specific interactions of cells with abiotic and biotic surfaces [18]. Supposedly, the disintegration products, which are structural components of lactic acid bacteria, can disrupt the biofilm formation by shielding cell surface adhesins and changing its physicochemical properties.

Analysis of the data suggests that the different directionality and degree of influence of the studied cell-free extracts on the basic physiological functions of $L$. reuteri are due to differences in their composition, which is predetermined by the method of preparation and by the type of derivatives' producer. It is obvious that extracts from disintegrates, obtained by repeated freezing-thawing of a bacterial suspension, contain the structural components of bacterial cells (MAMPs, microbe-associated molecular patterns) and bacterial cold shock proteins (DAMPs, damage-associated molecular patterns). These structures possess powerful bioregulatory potential. For example, cold induced proteins have the ability to orchestrate multiple cellular processes, including proliferation and differentiation by regulation of transcription, translation, and splicing 
$[11,12,20]$. Extracts from probiotic cultures additionally contain metabolic products of actively proliferating cells. Some substances can be catabolized by lactobacilli and serve as signaling molecules involved in the regulation of gene expression and in the quorum sensing mechanism implementation. Elucidation of the mechanism of action requires further careful study of the biochemical composition of cell-free extracts.

\section{Conclusions}

1. The results of the study allow us to positively evaluate the prospects for the creation of new metabiotics based on probiotic derivatives.

2. Cell-free extract, obtained from $L$. reuteri culture, grown in its own disintegrate supplemented with glycerol and glucose can contribute to the survival and facilitate inoculation of the introduced probiotic in the gastrointestinal tract when used together.

3. Derivative-containing extracts with a pronounced growth-stimulating effect can be the basis for creating of means for increasing the overall productivity of probiotic cell biomass. The use of such means will increase the economic efficiency of the production of probiotic cultures.

4. Obtained data induce further study of the biochemical composition, elucidation of the mechanism of action of cell-free extracts and confirmation of their efficacy in vivo.

Prospects for further research: obtained results are of practical importance and will be used in the development of new metabiotics and means for increasing the overall productivity of cell probiotic biomass based on $B$. bifidum and $L$. reuteri derivatives.

\section{Acknowledgment}

I would like to express my deep gratitude to my scientific advisor MD, PhD, DSc, Professor Yevhen Babich for sharing his valuable advices with me during the course of this research. I would also like to express special gratitude to my colleague, MD, $\mathrm{PhD}$, leading research worker Olena Isaienko for assistance in experimental work.

\section{Funding}

The study is a fragment of the research project of the laboratory of respiratory infections prevention, State Institution "I. Mechnikov Institute of Microbiology and Immunology of National Academy of Medical Sciences of Ukraine", "Microbiological characteristic of new structural and metabolic complexes of lacto- and bifidoprobiotics" (state registration No. 0119U100686).

Conflicts of interest: author has no conflict of interest to declare. Конфлікт інтересів: віАсутній.

Надійшла Ао реАакції / Received: 05.02.2019

Після Аоопрацювання / Revised: 14.03.2019

Прийнято Ао Аруку / Accepted: 25.03.2019

Information about author:

Knysh 0. V., MD, PhD, Senior Researcher of the Laboratory of Respiratory Infections Prevention, State Institution

"I. Mechnikov Institute of Microbiology and Immunology of National Academy of Medical Sciences of Ukraine", Kharkiv. ORCID ID: 0000-0002-4105-1299
Відомості про автора:

Книш О. В., канА. меА. наук, старший науковий співробітник лабораторії профілактики краплинних інфекцій, АУ «|нститут мікробіології та імунології імені І. І. Мечникова НАМН України", м. Харків.

\section{Сведения об авторе:}

Кныш О. В., канА. меА. наук, старший научный сотрудник лаборатории профилактики капельных инфекций, ГУ "Институт микробиологии и иммунологии имени И. И. Мечникова НАМН Украины", г. Харьков.

\section{References}

[1] Britton, R. (2017). Lactobacillus reuteri. The Microbiota In Gastrointestinal Pathophysiology, 89-97. doi: 10.1016/b978-0-12-804024-9.00008-2

[2] Mu, Q., Tavella, V., \& Luo, X. (2018). Role of Lactobacillus reuteri in Human Health and Diseases. Frontiers In Microbiology, 9. doi: 10.3389/ fmicb.2018.00757

[3] Kahouli, I., Malhotra, M., Tomaro-Duchesneau, C., Saha, S., Marinescu, D., Rodes, L. S., et al. (2015). Screening and in-vitro analysis of Lactobacillus reuteri strains for short chain fatty acids production, stability and therapeutic potentials in colorectal cancer. Journal of Bioequivalence \& Bioavailability, 7(1), doi: 0.4172/jbb.1000212

[4] Walter, J., Britton, R., \& Roos, S. (2011). Host-microbial symbiosis in the vertebrate gastrointestinal tract and the Lactobacillus reuteri paradigm. Proceedings Of The National Academy Of Sciences, 108(Supplement 1), 4645-4652. doi: 10.1073/pnas.1000099107

[5] Mills, J., Weinstein, P., Gellie, N., Weyrich, L., Lowe, A., \& Breed, M. (2017). Urban habitat restoration provides a human health benefit through microbiome rewilding: the Microbiome Rewilding Hypothesis. Restoration Ecology, 25(6), 866-872. doi: 10.1111/rec.12610

[6] Urbańska, M., \& Szajewska, H. (2014). The efficacy of Lactobacillus reuteri DSM 17938 in infants and children: a review of the current evidence. European Journal Of Pediatrics, 173(10), 1327-1337. doi: 10.1007/s00431-014-2328-0

[7] Sližová, M., Nemcová, R., Mad'ar, M., Hadryová, J., Gancarčíková, S., Popper, M., \& Pistl, J. (2015). Analysis of biofilm formation by intestinal lactobacilli. Canadian Journal Of Microbiology, 61(6), 437-446. doi: 10.1139/cjm-2015-0007

[8] Navarro, J., Mashburn-Warren, L., Bakaletz, L., Bailey, M., \& Goodman, S. (2017). Enhanced Probiotic Potential of Lactobacillus reuteri When Delivered as a Biofilm on Dextranomer Microspheres That Contain Beneficial Cargo. Frontiers In Microbiology, 8. doi: 10.3389/ fmicb.2017.00489

[9] Mackos, A., Galley, J., Eubank, T., Easterling, R., Parry, N., Fox, J., et al. (2016). Social stress-enhanced severity of Citrobacter rodentium-induced colitis is CCL2-dependent and attenuated by probiotic Lactobacillus reuteri. Mucosal Immunology, 9(2), 515-526. doi: 10.1038/ mi.2015.81

[10] Stefania, D., Miranda, P., Diana, M., Claudia, Z., Rita, P., \& Donatella, P. (2017). Antibiofilm and Antiadhesive Activities of Different Synbiotics. Journal Of Probiotics \& Health, 5(3). doi: 10.4172/23298901.1000182

[11] Shenderov, B. (2013). Metabiotics: novel idea or natural development of probiotic conception. Microbial Ecology In Health \& Disease, 24. doi: 10.3402/mehd.v24i0.20399

[12] Singh, A., Vishwakarma, V., \& Singhal, B. (2018). Metabiotics: the functional metabolic signatures of probiotics: current state-of-art and future research priorities-Metabiotics: probiotics effector molecules. Advances In Bioscience And Biotechnology, 9, 147-189. doi: 10.4236/ abb.2018.94012

[13] Landman, C., \& Quévrain, E. (2016). Le microbiote intestinal: description, rôle et implication physiopathologique. La Revue de Médecine Interne, 37(6), 418-423. doi: 10.1016/j.revmed.2015.12.012

[14] Sposib oderzhannia biolohichno aktyvnykh deryvativ bakterii probiotychnykh shtamiv. pat. 122859 Ukraina [Method for obtaining biologically active derivatives of probiotic strains bacteria. pat. 122859]. I Knysh, O. V., Isaienko, O. Yu., Babych, Ye. M., Polianska, V. P., Zachepylo, S. V., Kompaniiets, A. M., et al. № u201708828 ; zaiavl. 04.09.17 ; opubl. 25.01.18, biul. 2. [in Ukrainian].

[15] Stepanović, S., Vuković, D., Hola, V., Bonaventura, G., Djukić, S. Ćirković, I., et al. (2007). Quantification of biofilm in microtiter plates: overview of testing conditions and practical recommendations for assessment of biofilm production by staphylococci. APMIS, 115(8), 891-899. doi: 10.1111/j.1600-0463.2007.apm 630.x

[16] In Lee, S., Barancelli, G., de Camargo, T. M., Corassin, C. H., Rosim, R. E., da Cruz, A., et al. (2017). Biofilm-producing ability of Listeria monocytogenes isolates from Brazilian cheese processing plants. Food Research International, 91, 88-91. doi: 10.1016/j.foodres.2016.11.039 
[17] Tachedjian, G., Aldunate, M., Bradshaw, C., \& Cone, R. (2017). The role of lactic acid production by probiotic Lactobacillus species in vaginal health. Research in Microbiology, 168(9-10), 782-792. doi: 10.1016/j. resmic.2017.04.001

[18] Lebeer, S., Vanderleyden, J., \& De Keersmaecker, S. (2008). Genes and molecules of lactobacilli supporting probiotic action. Microbiology and Molecular Biology Reviews, 72(4), 728-764. doi: 10.1128/ MMBR.00017-08

[19] Ranieri, M., Whitchurch, C., \& Burrows, L. (2018). Mechanisms of biofilm stimulation by subinhibitory concentrations of antimicrobials. Current Opinion in Microbiology, 45, 164-169. doi: 10.1016/j.mib.2018.07.006

[20] Lindquist, J., \& Mertens, P. (2018). Cold shock proteins: from cellular mechanisms to pathophysiology and disease. Cell Communication and Signaling, 16(1). doi: 10.1186/s12964-018-0274-6 